\title{
Revive the Federal Parole System Sundiata Acoli
}

\section{Parole Chair Who Denied Sundiata Parole LINKED TO MobSTERS}

Andrew Consovoy is the New Jersey Parole Board member, along with then Chairperson, Mary DiSabato, who denied Sundiata parole and gave him a 20 year "hit" in 1993. By the summer of 1998, Disabato had quietly resigned and Governor Christine Whitman quietly elevated Consovoy to Chairman of the Parole Board without the normal media announcements and fanfare usually accompanying the appointment of a new Chairman. Friends of Consovoy were not so reserved. They held a lively celebration of his promotion at Trenton's "Roma" restaurant, and guess who came to dinner? Well, there was Consovoy, the guest of honor, and Dennis Steo who apparently paid for the party. Steo had been released by Consovoy and the rest of the Parole Board in 1995 after serving a lengthy sentence for two murders. Law enforcement sources said Steo used to be the enforcer for the Philadelphia mob. His boss was Albert "Red" Potani, reputedly a made member of the organization. Party guests saw Consovoy walk over, shake hands and sit down in conversation with Steo.

Also present at the party was Joseph "Gus" Ferrera, who Consovoy admits is one of his best friends. Ferrera is an ex-con and former jail guard who was convicted in the late 1970s for helping Robert Spagnola escape from the Essex County jail. Spagnola was a Newark police officer and county sheriff officer before he started shaking down drug dealers. He moved on to run the Lucchese crime family's sport gambling operation in New Jersey and has been in and out of prison many times since. Ferrera was sentenced to three years with a mandatory two years in prison without parole in the Spagnola affair, yet Ferrera was paroled after seven months. Before his parole was over he was hired by New Jersey state to be an "ombudsman" for the Department of Corrections (DOC). At the time Consovoy was in charge of co-ordinating gubernatorial appointments for the Governor. Ferrera is 72 years old and draws a paycheck of $\$ 73,000$ for the unusual Passaic County Jail job of helping prisoners prepare for parole. No other county jail has such a post. Although Ferrera is a DOC employee, not a Parole Board employee, he's frequently seen at the Parole Board Office in Trenton and has considerable access to Consovoy, Parole Board employees say.

Consovoy recently attended the wedding of Ferrera's daughter and also used Ferrera's condo in Marco Island, Florida, this spring for vacation. 
Ferrera is the cousin of Michael Taccetta, the former New Jersey boss of the Lucchese Family. Consovoy's son played on the basketball team with the son of Marty Taccetta, Michael's younger brother who's also a reported mobster. Consovoy said naturally he got to know Marty Taccetta, but the link was purely social. Consovoy is the target of a state criminal investigation into the possible early release of a number of mobsters or others with "connections". One released was Clifton mobster, Samuel Corsaro, known to law enforcement sources as a major figure in the Gambino crime family. Corsaro walked out of prison on February 14th, after serving minimum time for parole despite a long prison record and previous parole violations. Another is Jason J. Guerrera, the son of a Superior Court judge in Atlantic City, who served twenty months on a seven year term for manslaughter. His accomplice is still in prison. Consovoy will also be questioned about the backlog of thousands of prisoners who have waited months and even years after their eligibility dates to have their cases heard by the Parole Board. The overwhelming majority, 90 per cent, of New Jersey's prisoners are Black or Latino.

Consovoy is the same Parole Board member who vilified Sundiata in the media and crowed about giving him the 20 year hit, the longest in state history. All the while, he was quietly giving preferential treatment and early releases to his pal mobsters. Sundiata's lawyers appealed Consovoy and the Parole Board's decision on grounds that it was biased and an abuse of their power. Sundiata has done almost 28 years in prison.

A fair court decision could result in an order that Sundiata be paroled.

\section{What You Can Do}

Under the present system most federal prisoners must serve 85 per cent of their sentences before being released. Almost no provisions exist for federal prisoners to earn early release through good behavior, superior work performance, outstanding achievements and the like. A federal prisoner sentenced to 10 years today must serve 8 and a half years before being released; one sentenced to 20 years must serve 17 years before release, no ifs, ands or buts.

Under the old Federal Parole System all first-offenders were eligible for parole after serving one-third of their sentence. Also, most were actually 
paroled after completing one-third of their sentence and all reached "mandatory release" upon serving two-thirds of their sentence. A federal prisoner sentenced to 10 years under the old laws was usually paroled after doing three and one-third years and reached mandatory release at six and two-thirds years; one sentenced to 20 years was normally paroled after six and two-thirds years, or received mandatory release after 13 and one-third years.

Now Congressman Danny Davis (D-IL) has introduced to the House, HR 3072, a bill "To Revive the System of Parole for Federal Prisoners". In order to get this bill passed he needs the support of other congresspersons nation-wide.

Write and/or call your Congressperson (see below for contact information) and urge him/her to co-sponsor HR 3072, a bill "To Revive the System of Parole for Federal Prisoners", so that:

- Your family member, loved one or friend in the federal prison may be released early and reunited with you earlier;

- Billions of tax dollars being spent to confine mostly non-violent drug offenders can be saved or diverted to better and proven methods of solving drug abuse and addiction problems; and/or,

- A safer society can be built by promoting rehabilitation, shorter incarceration times for deserving prisoners, relief of dangerous prison overcrowding, prohibition of another wasteful and futile spree of prison-building and promotion of a better use of public funds to strengthen needed social programs.

After you write and/or call your Congressperson, get your family members and friends to write/call their Congresspersons.

To get your Congresspersons address(es) and telephone numbers access http://www.visi.com/juan/congress and click on your state. It will give you all contact information for your Congressperson. Write your Congressperson at her/his local office. It will reach him/her faster. Letters to his/her Washington D.C. address will be delayed several months while being checked for anthrax. 
Learn more about Sundiata Acoli at www.afrikan.net/sundiata and www. assatashakur.org and write to him at:

Sundiata Acoli, 39794-066

National Jericho Movement

P.O. Box 3000

P.O. Box 340084

USP Allenwood Jamaica, NY 11434

White Deer, PA 17887

\section{REFERENCES}

"Parole Chief Has Dubious Mobsters at Party" by Thomas Zolper, The Record, Northern New Jersey, 6/11/2000.

"NJ Parole Chief's Relationships Under Scrutiny", Associated Press Newswires, $6 / 11 / 2000$

"Parole Chief to Meet with Governor Whitman" by Brian Donohue, The Star Ledger, Newark, NJ, 6/13/2000. 